\title{
Investigation of Natural Gamma Radioactivity Levels and Associated Dose Rates from Surface Soils in Ore Metropolis, Ondo State, Nigeria
}

\author{
Margaret Kofoworola Akinloye (Corresponding author) \\ Department of Pure and Applied Physics \\ Ladoke Akintola University of Technology \\ P.M.B. 4000, Ogbomoso, Nigeria
}

Tel: 234-803-357-5302Ｅ-mail: kofoworolaakinloye@yahoo.co.uk

\author{
Gbadebo Adebisi Isola \\ Department of Pure and Applied Physics \\ Ladoke Akintola University of Technology \\ P.M.B. 4000, Ogbomoso, Nigeria
}

Tel: 234-803-359-8710Ｅ-mail: isoladebo@yahoo.com

\author{
Olukunle Olaonipekun Oladapo \\ Department of Science Laboratory Technology \\ Ladoke Akintola University of Technology \\ P.M.B. 4000, Ogbomoso, Nigeria \\ Tel: 234-802-718-9034Ｅ-mail: mixwealthacada@yahoo.com
}

Received: December 20, $2011 \quad$ Accepted: January 28, $2012 \quad$ Published: March 1, 2012

doi:10.5539/enrr.v2n1p140 URL: http://dx.doi.org/10.5539/enrr.v2n1p140

\begin{abstract}
Natural radioactive materials under certain conditions can reach hazardous radiological levels. Therefore, it becomes necessary to study the natural radioactivity levels in soil to assess the dose to the population in order to determine the health risks and to obtain a baseline for future changes that may occur due to human activities.

The motivation for this study was the devastating civil war that took place in Nigeria from 1967 to 1970, in which the study area was one of the battle fields. The results of our investigations of the soil in the metropolis of Ore show that the activity concentrations of ${ }^{226} \mathrm{Ra},{ }^{232} \mathrm{Th}$ and ${ }^{40} \mathrm{~K}$ in the soil vary from $14.21 \pm 1.40$ to $25.87 \pm 1.01 \mathrm{~Bq} / \mathrm{kg}$; $5.30 \pm 1.00$ to $20.99 \pm 1.10 \mathrm{~Bq} / \mathrm{kg}$ and $58.01 \pm 1.80$ to $382.98 \pm 3.00 \mathrm{~Bq} / \mathrm{kg}$ respectively.

The total absorbed dose rate calculated from the activity concentrations of ${ }^{226} \mathrm{Ra},{ }^{232} \mathrm{Th}$ and ${ }^{40} \mathrm{~K}$ ranged from $15.42 \pm 1.10$ to $40.99 \pm 1.36 \mathrm{nGy} / \mathrm{h}$. The radium equivalent activity $\left(\mathrm{R}_{\mathrm{eq}}\right)$ and the annual effective dose rates were also calculated and found to vary from $33.39 \pm 2.44$ to $85.07 \pm 2.96 \mathrm{~Bq} / \mathrm{kg}$ and from $18.91 \pm 1.35$ to $50.27 \pm 1.69 \mu \mathrm{Sv} / \mathrm{y}$ respectively. These values were found to be within the same range as recommended values (UNSCEAR, 2000). The study also indicated that ${ }^{137} \mathrm{Cs}$ detected at three locations is an indication of the presence of artificial radionuclides which can be linked to the war that took place in the ancient town of Ore.
\end{abstract}

Keywords: Gamma Radioactivity, Dose rate, Battle field, Ore

\section{Introduction}

The knowledge of radionuclide distribution and radiation levels in the environment is important for assessing the effects of radiation exposure due to terrestrial, cosmogenic and human activities. Radiation exposure can occur in two ways: from sources outside the body (external exposure) and from radioactive substances contained in the food or water consumed or in the air inhaled (internal exposure). 
The natural radioactivity in soil comes mainly from the series radionuclides headed by ${ }^{238} \mathrm{U},{ }^{232} \mathrm{Th}$ and from natural ${ }^{40} \mathrm{~K}$. Some other terrestrial sources including those of the ${ }^{235} \mathrm{U}$ series, ${ }^{87} \mathrm{Rb},{ }^{138} \mathrm{La}$ and ${ }^{176} \mathrm{Lu}$ exist in nature but at such low levels that their contributions to the dose to humans are considered insignificant. Artificial radionuclides can also be present such as ${ }^{137} \mathrm{Cs}$ is resulting from fallout from weapons testing and some other human activities involving the use of these radionuclides (Walling \& Quine, 1991; Wu \& Tiessen, 2002; Schoorl et al., 2004; Heckrath et al., 2005). The radiological implication of these radionuclides is due to the gamma-ray exposure of the body and irradiation of lung tissue from inhalation of radon and its progenies.

Radioisotopes that are present in soil significantly affect terrestrial gamma radiation levels. Several studies have been carried out to assess the average outdoor terrestrial gamma dose rate in air at $1 \mathrm{~m}$ from the ground. These studies determined that the effective gamma radiation levels were generally in the range of $10-200 \mathrm{nGyh}^{-1}$ with a mean of $60 \mathrm{nGyh}^{-1}$ (UNSCEAR, 2002)

The objective of this study is to evaluate and map soil radioactivity concentrations as well as environmental outdoor gamma dose rates in Ore metropolis, Ondo State, South - Western Nigeria.

The town came to limelight as a result of the historic battle that took place there during the Nigerian civil war between 1967 and 1970. Until now, there has not been a comprehensive study evaluating background radiation levels in the town. Hence, this work would provide data on the background radioactivity levels and in addition, determine the impact of the weapons of war that could have contributed to the contamination of the environment.

\section{Methodology}

In order to have a good representative sampling of the entire environment, the study area was divided into 25 grids from which samples were collected. In each grid, five different points were sampled. Figure 1 shows the map of Ore indicating the locations in each grid where the samples were collected. A total of 125 samples were collected from the 25 locations across the study area. Samples were obtained from uncultivated locations that were close to settlements. Flat, open and undisturbed geographical locations which had good water permeability were selected as the sampling points. Efforts were made however to ensure that surface vegetation such as grass, weed, leaves e.t.c were removed before collecting the samples.

The first $10 \mathrm{~cm}$ of topsoil was taken as most of the ${ }^{137} \mathrm{Cs}$ is stored in these layers (Schimmack et al., 1989; Owens et al., 1996; Schoorl et al., 2004); foreign bodies were removed and the remaining soil samples were set for laboratory preparation. The samples were dried at room temperature to a constant weight. This is in a bid to avoid any external factors that might alter their natural radionuclide content. The samples were then passed through $2 \mathrm{~mm}$ sieves and packed in suitable sample containers. The samples remained tightly sealed in the containers for about 28 days which was a sufficient time required to attain a state of secular radioactive equilibrium (Karaham \& Bayulken, 2000). A gamma spectrometry system with $\mathrm{NaI}(\mathrm{Tl})$ as the detector was employed for the analysis. The system was calibrated using standard point sources of gamma emitting isotopes. Each sealed sample after attaining secular equilibrium was placed on the detector and counted for 36000 s.

The activity concentrations of the samples were determined using the total net counts under the selected photopeaks, the measured photopeak efficiency, gamma intensity and mass of the samples. After correcting for background and Compton contribution, the activity concentrations of ${ }^{232} \mathrm{Th},{ }^{226} \mathrm{Ra}$ and ${ }^{40} \mathrm{~K}$ were determined. Equation 1 gives the relationship between the concentration $\mathrm{A}_{\mathrm{C}}$ and other parameters.

Where;

$$
A_{C}=\frac{C_{n e t}}{I_{\lambda} \times E_{f f}\left(E_{\lambda}\right) \times m}
$$

$\mathrm{C}_{\text {net }}$ is the net peak counts.

$I_{\gamma}$ is absolute gamma decay intensity for the specific energy photopeak (including the decay branching ratio information).

$E_{\mathrm{ff}}\left(\mathrm{E}_{\gamma}\right)$ is the absolute efficiency of the detector at this energy and $\mathrm{m}$ is the mass of the sample in $\mathrm{kg}$.

\section{Results and Discussion}

The mean specific activities determined from the measurements of 125 samples are as presented in Table 1 . The data recorded in this work show that the radionuclides detected in the soil samples belong to the natural radionuclide series headed by ${ }^{226} \mathrm{Ra},{ }^{228} \mathrm{Ra}$, and ${ }^{40} \mathrm{~K}$ concentrations as well as the concentrations of man-made radionuclide ${ }^{137} \mathrm{Cs}$. The activities concentration was within the range of values for normal background area (Akinloye \& Olomo, 1995). In general the values of the average activity concentrations of ${ }^{226} \mathrm{Ra},{ }^{232} \mathrm{Th}$ and ${ }^{40} \mathrm{~K}$ in 
the soil samples measured vary from $14.20 \pm 1.40$ to $26.32 \pm 2.01 ; 5.30 \pm 1.00$ to $20.99 \pm 1.10$; and $58.01 \pm 1.80$ to $382.98 \pm 3.00$ respectively. These values are comparable with the World figures reported in UNSCEAR (2000).

${ }^{137} \mathrm{Cs}$ was detected at three locations with values varying between $0.78 \pm 0.10$ and $3.21 \pm 0.30$. The presence of ${ }^{137} \mathrm{Cs}$ may be due to the contamination of the soil as a result of the weapons used during the civil war. (Faw $\&$ Shultis, 1993; Cooper et al., 2003; NCRP, 2006)

Also in table 2, the total absorbed dose rate was determined from the activity concentration of ${ }^{226} \mathrm{Ra},{ }^{227 \mathrm{Th}}$ and ${ }^{40} \mathrm{~K}$ ranged from $15.42 \pm 1.10$ to $40.99 \pm 1.36 \mathrm{nGy} / \mathrm{h}$. The radium equivalent activity $\left(\mathrm{R}_{\mathrm{eq}}\right)$ and the annual effective dose rates were also calculated and found to vary from $33.39 \pm 2.44$ to $85.07 \pm 2.96 \mathrm{~Bq} / \mathrm{kg}$ and from $18.91 \pm 1.35$ to $50.27 \pm 1.69 \mu \mathrm{Sv} / \mathrm{y}$ respectively.

\subsection{Gamma Dose Rate (D)}

The calculated values of the total absorbed dose rate of the soil samples measured are represented in Table 2 . Gamma dose rate (D) in the outdoor air at $1 \mathrm{~m}$ above the ground level was calculated using equation 2; (UNSCEAR, 2000)

$$
D=\left(R_{K} \times Q_{K}\right)+\left(R_{U} \times Q_{U}\right)+\left(R_{T h} \times Q_{T h}\right)
$$

Where $R_{k}(0.042), R_{U}(0.430)$ and $R_{T h}(0.666)$ are the conversion factors for ${ }^{40} K$ and the series radionuclides ${ }^{238} \mathrm{U}$ and ${ }^{232} \mathrm{Th}$ respectively (UNSCEAR, 2000). $\mathrm{Q}_{\mathrm{K}}, \mathrm{Q}_{\mathrm{U}}$ and $\mathrm{Q}_{\mathrm{Th}}$ are the activity concentrations of ${ }^{40} \mathrm{~K},{ }^{238} \mathrm{U}$ and ${ }^{232} \mathrm{Th}$ respectively in $\mathrm{Bq} / \mathrm{kg}$. The values of the dose rates obtained vary from a least value of $15.42 \mathrm{nGy} / \mathrm{h}$ for the soil of location R.18 to a highest value of $40.99 \mathrm{nGy} / \mathrm{h}$ for soil of location R.2. These values fall within the same range as the maximum admissible dose rate of $55 \mathrm{nGy} / \mathrm{h}$. (UNSCEAR, 2000).

\subsection{Radium Equivalent Activity ( $\left.R a_{e q}\right)$}

Radium equivalent activity is used to assess the hazards associated with materials that contain ${ }^{226} \mathrm{Ra},{ }^{232} \mathrm{Th}$ and ${ }^{40} \mathrm{~K}$ in $\mathrm{Bq} / \mathrm{kg}$. This can be calculated using equation 3:

$$
\mathrm{Ra}_{\mathrm{eq}}=\left(\mathrm{Q}_{\mathrm{K}} \times 0.077\right)+\left(\mathrm{Q}_{\mathrm{U}}\right)+\left(\mathrm{Q}_{\mathrm{Th}} \times 1.43\right)
$$

The $\mathrm{Ra}_{\mathrm{eq}}$ activity values calculated in this work range between 33.39 to $85.07 \mathrm{~Bq} / \mathrm{kg}$ and these are presented in Table 2. The published maximum admissible $\mathrm{Ra}_{\mathrm{eq}}$ is $370 \mathrm{~Bq} / \mathrm{kg}$. The results of this work are lower than the suggested maximum value.

\subsection{External Hazard Index $\left(H_{e x}\right)$}

The external hazard index is an evaluation of the hazard of the natural gamma radiation. It can be calculated from equation 4 .

$$
H_{e x}=\frac{Q_{U}}{370}+\frac{Q_{T h}}{259}+\frac{Q_{k}}{4810} \leq 1
$$

The value of $\mathrm{H}_{\text {ex }}$ obtained in this work is 0.1361 . Since this value is lower than unity the soil from the metropolis may be used both for building or agriculture without posing any significant radiological threat to the population (European Commission, 1999).

\subsection{Annual Effective Dose Equivalent (AEDE)}

In order to estimate the annual effective dose rate in air the conversion coefficient from absorbed dose in air to effective dose received by an adult had to be taken into the consideration. The annual effective dose equivalent is given by equation 5 (UNSCEAR 2000).

$$
\text { AEDE }(\mu S y / y)=D\left(n G / h \times 8760(h / y) \times 0.2 \times 0.7(S y / G y) \times 10^{-3}\right.
$$

The results obtained are presented in Table 2 . The highest annual effective dose rate value was found to be 50.27 $\mu \mathrm{Sv} / \mathrm{y}$, while the lowest value was $18.9 \mu \mathrm{Sv} / \mathrm{y}$. The World average annual effective dose is approximately $70 \mu \mathrm{Sv} / \mathrm{y}$. The values obtained in this study are all lower than the accepted, average worldwide value.

\section{Conclusion}

Investigation and analysis of the radioactivity in the soil of Ore metropolis, South West Nigeria had been undertaken in this work. The activity concentrations of ${ }^{226} \mathrm{Ra},{ }^{232} \mathrm{Th}$ and ${ }^{40} \mathrm{~K}$ obtained in the soil vary from $14.21 \pm 1.40$ to $25.87 \pm 1.01 \mathrm{~Bq} / \mathrm{kg} ; 5.30 \pm 1.00$ to $20.99 \pm 1.10 \mathrm{~Bq} / \mathrm{kg}$ and $58.01 \pm 1.80$ to $382.98 \pm 3.00 \mathrm{~Bq} / \mathrm{kg}$ respectively. The total absorbed dose rate calculated from the activity concentrations of ${ }^{226} \mathrm{Ra},{ }^{232} \mathrm{Th}$ and ${ }^{40} \mathrm{~K}$ ranged from $15.42 \pm 1.10$ to $40.99 \pm 1.36 \mathrm{nGy} / \mathrm{h}$. The radium equivalent activity $\left(\mathrm{R}_{\mathrm{eq}}\right)$ and the annual effective dose rates were also calculated and found to vary from $33.39 \pm 2.44$ to $85.07 \pm 2.96 \mathrm{~Bq} / \mathrm{kg}$ and from $18.91 \pm 1.35$ to $50.27 \pm 1.69 \mu \mathrm{Sv} / \mathrm{y}$ respectively. ${ }^{137} \mathrm{Cs}$ was detected at three locations at very low values varying between $0.78 \pm 0.10$ 
and $3.21 \pm 0.30$. It is however known that these locations according to our finding are the areas where the battle was concentrated.

The results of this work can be considered as baseline data for the natural background radioactivity levels of the town and would in future facilitate assessment of any enhancement that may occur in this environment.

\section{Acknowledgements}

We would like to thank the leadership of the Department of Pure and Applied Physics, Ladoke Akintola University of Technology (LAUTECH) Ogbomoso, Nigeria for access to the facilities of the Radiation and Health Laboratory of the Department.

\section{References}

Akinloye, M.K., \& Olomo, J.B. (1995). Survey of Environmental Radiation Exposure Around Obafemi Awolowo University Nuclear Research Facilities. Nigerian Journal of Physics, 7, 16-19.

Cooper, J.R., Randle, K., \& Sokhi, R.S. (2003). Radioactive Releases in the Environment: Impact and Assessment. John Wiley \& Sons, West Sussex.

European Commission. (1999). Radiation Protection 112. Radiological Protection Principles concerning the Natural Radioactivity of Building Materials. European Commission, Brussels.

Faw, R.E. \& Shultis, J.K. (1993). Radiological Assessment: Sources and Exposures. Prentice-Hall, New Jersy.

NCRP. (2006). Cesium-137 in the Environment: radioecology And Approaches to Assessment and Management. Report 154, National Council on Radiation Protection and Measurements, Bethesda, MD., Owens, P.N., Walling, D.E., \& He, Q.P. (1996). The behaviour of bomb - derived caesium - 137 fallout in catchments soils. Journal of Environmental Radioactivity, 32, 169-191.

Schimmack, W., Bunzl, K., \& Zelles, I. (1989). Initial rates of migration of radionuclides from the Chernobyl fallout in undisturbed soils. Geoderma, 44, 211-218. http://dx.doi.org/10.1016/0016-7061(89)90030-X

Schoorl, J.M., Boix Fayos, C., de Meijer, R.J., van der Graaf, E.R., \& Veldkamp, A. (2004). The Cs - 137 techniques applied to steep Mediterranean slopes (part I): the effect of lithology, slope morphology and land use. Catena 57, 15-34. http://dx.doi.org/10.1016/j.catena.2003.08.003

UNSCEAR. (2000). Annex A: United Nations Scientific Committee on the Effects of Atomic Radiation, REPORT 2000, Vol. I. Annex A; Dose Assessment Methodologies.

UNSCEAR. (2000). Annex B: United Nations Scientific Committee on the Effects of Atomic Radiation, REPORT 2000, Vol. I. Annex B; Exposures from natural radiation sources.

UNSCEAR. (2000). Annex C: United Nations Scientific Committee on the Effects of Atomic Radiation, REPORT 2000, Vol. I. Annex C; Exposures from man-made sources of radiation.

UNSCEAR. (2000). Annex J, United Nations Scientific Committee on the Effects of atomic Radiation, 2000 REPORT, SOURCES AND EFFECTS OF IONIZING RADIATION, Vol. II, Annex J; Exposures and effects of the Chernobyl accident.

UNSCEAR. (2000). United Nations Scientific Committee on the Effects of Atomic Radiation. Effects and risks of ionizing radiations, UN, New York.

Walling, D.E., \& Quine, T.A. (1991). Use of ${ }^{137}$ Cs measurements to investigate soil erosion on arable fields in the UK: potential applications and limitations. Journal of Soil Science, 42, 147-165. http://dx.doi.org/10.1111/j.1365-2389.1991.tb00099.x

Wu, R.G., \& Tiessen, H. (2002). Effect of land use on soil degradation in alpine grassland soil, China. Soil Science Society of America Journal, 66, 1648-1655. http://dx.doi.org/10.2136/sssaj2002.1648 
Table 1. Radionuclide concentrations in the soil samples, $\mathrm{Bqkg}^{-1}$

\begin{tabular}{|c|c|c|c|c|c|}
\hline \multirow{2}{*}{$\begin{array}{c}\text { Sample } \\
\text { code }\end{array}$} & \multirow{2}{*}{ Sampling location } & \multicolumn{4}{|c|}{ Radionuclides } \\
\cline { 3 - 6 } & & Ra-226(U-238) & Th-232 & K-40 & Cs-137 \\
\hline R1 & ORITA OJO & $24.82 \pm 3.21$ & $6.88 \pm 0.90$ & $81.70 \pm 2.10$ & $<$ DL \\
\hline R2 & SOBOY & $25.56 \pm 1.16$ & $20.99 \pm 1.1$ & $382.98 \pm 3.00$ & $<$ DL \\
\hline R3 & AKINJAGBULA & $24.18 \pm 2.20$ & $14.59 \pm 1.2$ & $252.72 \pm 1.40$ & $<$ DL \\
\hline R4 & IDI MANGO & $24.01 \pm 0.33$ & $12.30 \pm 1.3$ & $183.63 \pm 2.20$ & $<$ DL \\
\hline R5 & ONISERA & $22.92 \pm 0.98$ & $7.82 \pm 1.10$ & $237.03 \pm 1.50$ & $<$ DL \\
\hline R6 & MOGABO & $25.55 \pm 2.98$ & $6.12 \pm 1.20$ & $72.11 \pm 1.70$ & $<$ DL \\
\hline R7 & MOBIL & $20.01 \pm 1.22$ & $13.50 \pm 1.1$ & $170.23 \pm 1.80$ & $<$ DL \\
\hline R8 & BAGBE & $14.21 \pm 1.40$ & $10.86 \pm 1.2$ & $188.80 \pm 2.30$ & $<$ DL \\
\hline R9 & IBUKUNOLUWA & $18.35 \pm 2.20$ & $12.45 \pm 1.3$ & $214.82 \pm 2.00$ & $<$ DL \\
\hline R10 & OMINLA & $19.08 \pm 3.20$ & $15.47 \pm 1.8$ & $382.97 \pm 2.50$ & $3.21 \pm 0.30$ \\
\hline R11 & SOMALI & $23.33 \pm 2.00$ & $11.66 \pm 1.4$ & $191.78 \pm 2.10$ & $<$ DL \\
\hline R12 & IDIARA & $26.32 \pm 2.01$ & $4.55 \pm 1.00$ & $58.01 \pm 1.80$ & $<$ DL \\
\hline R13 & AYOMIDE AREA & $25.87 \pm 1.01$ & $11.66 \pm 1.0$ & $132.22 \pm 1.70$ & $<$ DL \\
\hline R14 & OLOKUTA 1 & $23.99 \pm 1.00$ & $7.85 \pm 1.00$ & $110.45 \pm 2.00$ & $<$ DL \\
\hline R15 & AYO KOLA AREA & $24.33 \pm 1.60$ & $16.13 \pm 1.0$ & $294.11 \pm 3.20$ & $<$ DL \\
\hline R16 & TOTAL GARAGE & $24.00 \pm 1.20$ & $8.34 \pm 1.00$ & $102.78 \pm 2.40$ & $1.44 \pm 0.20$ \\
\hline R17 & MARKET & $18.20 \pm 0.60$ & $8.55 \pm 1.10$ & $191.16 \pm 1.30$ & $<$ DL \\
\hline R18 & SABO & $20.34 \pm 0.60$ & $3.88 \pm 1.20$ & $97.44 \pm 1.60$ & $<$ DL \\
\hline R19 & ODIGBO & $24.01 \pm 0.56$ & $8.05 \pm 1.10$ & $179.28 \pm 1.60$ & $<$ DL \\
\hline R20 & AGALU & $20.77 \pm 0.34$ & $12.45 \pm 1.30$ & $326.00 \pm 3.30$ & $<$ DL \\
\hline R21 & GAOGUNTASU & $23.33 \pm 0.44$ & $8.23 \pm 1.00$ & $133.22 \pm 3.50$ & $<$ DL \\
\hline R22 & RISAFU & $17.23 \pm 1.00$ & $9.00 \pm 1.10$ & $173.11 \pm 3.10$ & $<$ DL. \\
\hline R23 & OMIFON & $23.99 \pm 0.35$ & $6.14 \pm 1.00$ & $95.98 \pm 1.70$ & $<$ DL \\
\hline R24 & ASEWELE & $17.04 \pm 0.55$ & $8.03 \pm 1.00$ & $162.31 \pm 1.30$ & $<$ DL \\
\hline R25 & AJUE & $22.45 \pm 1.20$ & $5.30 \pm 1.00$ & $88.12 \pm 1.60$ & $0.78 \pm 0.10$ \\
\hline
\end{tabular}

Table 2. Absorbed dose rate, radium equivalent activity and annual effective dose equivalent in the soil of Ore Metropolis

\begin{tabular}{|c|c|c|c|c|}
\hline Sample code & Sampling location & $\mathbf{D}\left(\mathbf{n G y h}^{-\mathbf{1}}\right)$ & $\mathbf{R a}_{\mathbf{e q}}\left(\mathbf{B q k g} \mathbf{k g}^{-\mathbf{1}}\right)$ & $\mathbf{A E D E}\left(\boldsymbol{\mu S v y} \mathbf{}^{-1}\right)$ \\
\hline R1 & ORITA OJO & $18.69 \pm 2.02$ & $40.95 \pm 4.55$ & $22.92 \pm 2.54$ \\
\hline R2 & SOBOY & $40.99 \pm 1.36$ & $85.07 \pm 2.96$ & $50.27 \pm 1.67$ \\
\hline R3 & AKINJAGBULA & $30.66 \pm 1.80$ & $64.50 \pm 4.20$ & $37.60 \pm 2.21$ \\
\hline R4 & IDI MANGO & $26.23 \pm 1.02$ & $64.50 \pm 4.20$ & $37.60 \pm 2.21$ \\
\hline R5 & ONISERA & $25.01 \pm 1.73$ & $52.35 \pm 2.67$ & $30.67 \pm 1.26$ \\
\hline R6 & MOGABO & $25.01 \pm 1.73$ & $39.35 \pm 4.83$ & $22.19 \pm 2.12$ \\
\hline R7 & MOBIL & $24.74 \pm 1.40$ & $52.42 \pm 2.93$ & $30.34 \pm 1.72$ \\
\hline R8 & BAGBE & $21.23 \pm 1.68$ & $44.28 \pm 3.29$ & $26.04 \pm 2.06$ \\
\hline R9 & IBUKUNOLUWA & $25.17 \pm 1.90$ & $52.69 \pm 4.21$ & $30.87 \pm 2.33$ \\
\hline R10 & OMINLA & $34.55 \pm 2.68$ & $70.69 \pm 5.97$ & $42.37 \pm 3.29$ \\
\hline R11 & SOMALI & $25.18 \pm 1.78$ & $54.77 \pm 4.16$ & $31.65 \pm 2.18$ \\
\hline R12 & IDIARA & $16.78 \pm 1.53$ & $37.27 \pm 3.58$ & $20.58 \pm 1.88$ \\
\hline R13 & AYOMIDE AREA & $24.40 \pm 1.23$ & $52.72 \pm 2.57$ & $29.92 \pm 1.51$ \\
\hline R14 & OLOKUTA 1 & $20.48 \pm 1.33$ & $43.72 \pm 2.58$ & $24.75 \pm 1.63$ \\
\hline R15 & AYO KOLA AREA & $20.33 \pm 1.87$ & $70.04 \pm 3.28$ & $24.93 \pm 2.29$ \\
\hline R16 & TOTAL GARAGE & $20.19 \pm 1.20$ & $43.87 \pm 2.81$ & $24.76 \pm 1.47$ \\
\hline R17 & MARKET & $21.55 \pm 0.90$ & $45.15 \pm 2.27$ & $26.43 \pm 1.10$ \\
\hline R18 & SABO & $15.42 \pm 1.10$ & $33.39 \pm 2.44$ & $18.91 \pm 1.35$ \\
\hline R19 & ODIGBO & $23.21 \pm 1.04$ & $49.33 \pm 2.26$ & $28.46 \pm 1.28$ \\
\hline R20 & AGALU & $30.88 \pm 1.15$ & $63.68 \pm 2.45$ & $37.87 \pm 1.40$ \\
\hline R21 & GAOGUNTASU & $21.11 \pm 1.00$ & $45.36 \pm 2.14$ & $25.89 \pm 1.23$ \\
\hline R22 & RISAFU & $20.67 \pm 1.00$ & $43.43 \pm 2.81$ & $25.35 \pm 1.23$ \\
\hline R23 & OMIFON & $18.43 \pm 1.29$ & $40.16 \pm 1.91$ & $22.60 \pm 1.58$ \\
\hline R24 & ASEWELE & $19.49 \pm 0.96$ & $41.20 \pm 2.08$ & $23.90 \pm 1.18$ \\
\hline R25 & AJUE & $16.88 \pm 1.25$ & $36.81 \pm 1.67$ & $20.70 \pm 1.53$ \\
\hline
\end{tabular}




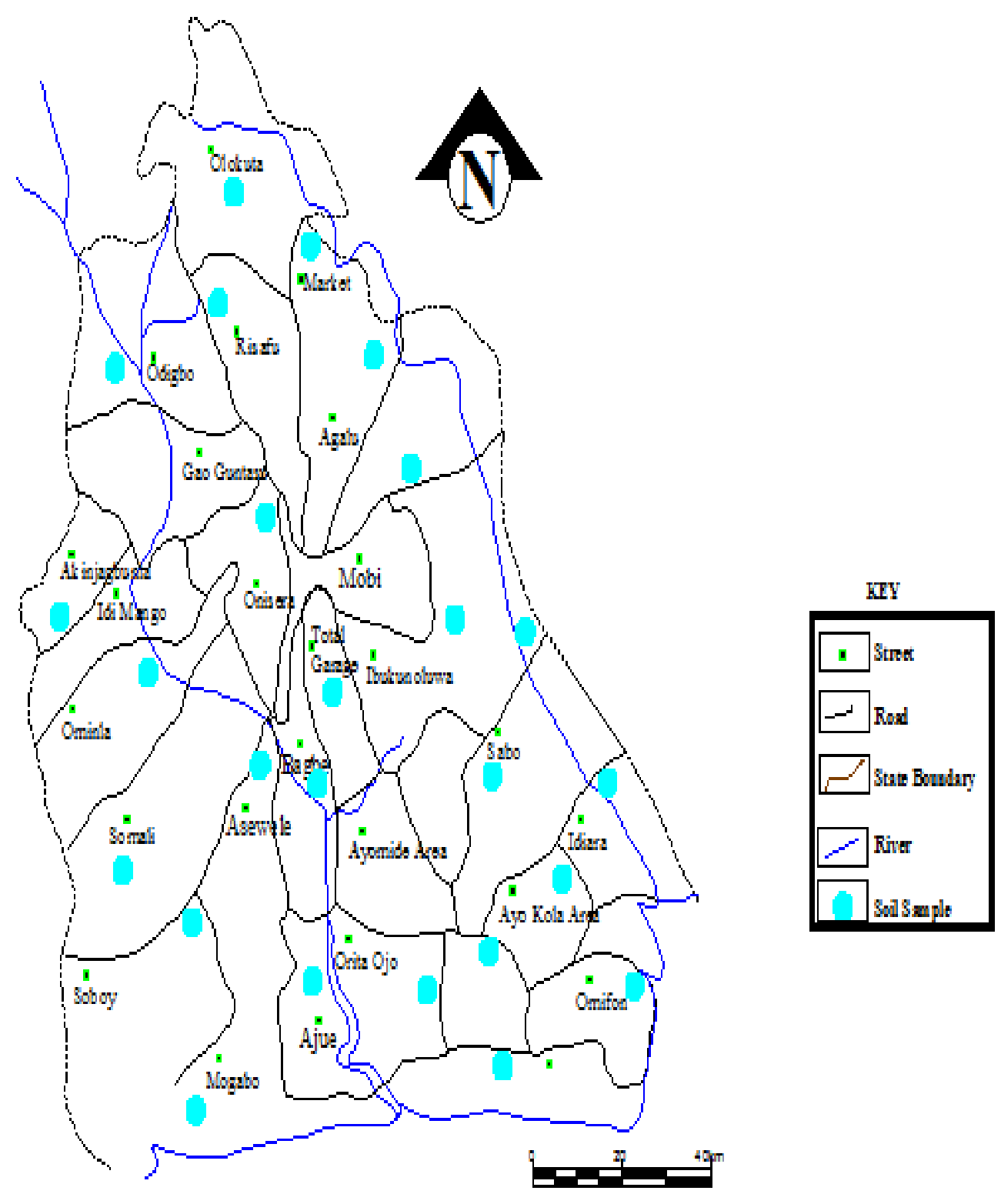

Figure 1. Map of Ore metropolis showing the sampling locations 